\title{
Pregled leta 2021
}

Matevž Triplat, Gozdarski inštitut Slovenije, Oddelek za gozdno tehniko in ekonomiko

Objavljeno na spletu 04.01.2022 (https://doi.org/10.20315/IG.2022.0001)

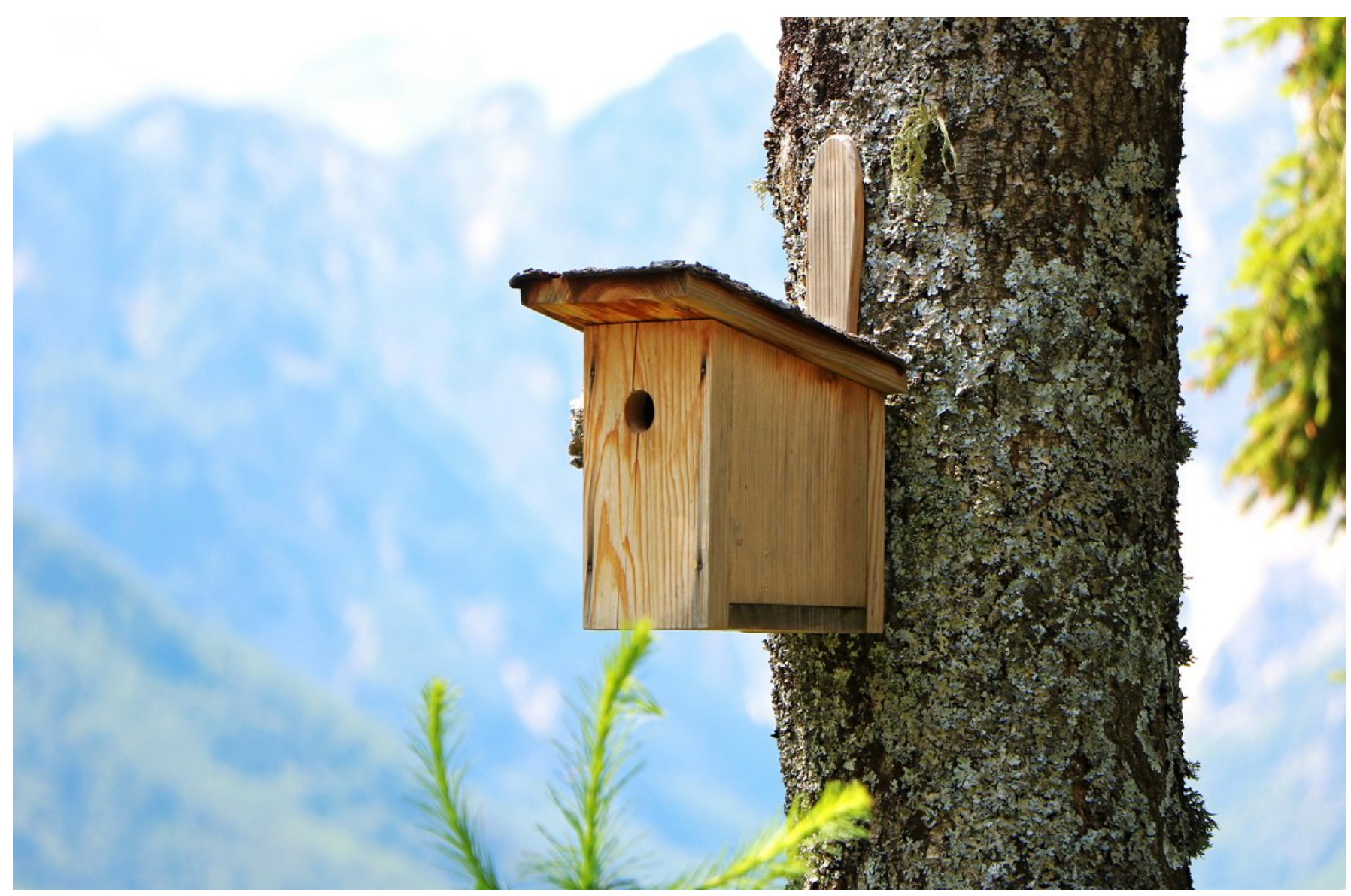

Za nami je še eno leto, ki ga je posredno in neposredno zaznamovala trajajoča pandemija, a kljub temu je za spletnim portalom WoodChainManager še eno markantno leto, ki je bistveno vplivalo na podobo spletnega portala v prihodnjih letih. Tekom leta smo na testnem strežniku izvajali celovito prenovo spletišča WoodChainManager in medtem na dobro poznani stari lokaciji še naprej vzdževali stik z zainteresirano javnostjo. Z redno objavo vsebin smo se trudili, da bi naši bralci čimmanj občutili tok prenavaljanja in sistemski sprememb.

Naposled je v mesecu oktorbu (2021) ugasnil stari portal WoodChainManager in luč sveta je ugledal nov celostno prenovljen portal WCM/InfoGozd. Med prvimi novostmi je prenovljen naziv. Staro ime po našem mnenju ne zadostuje širokemu spektru vsebin, ki jih danes ponujamo na spletni strani https://wcm.gozdis.si. Po novem je naziv spletne strani WCM - InfoGOZD. Z novim imenom "InfoGOZD" želimo stran približati domačim bralcem in poudariti novičarski - informativni del našega 
portala. Poleg spremenjenega naziva bodo tudi najmanj pozorni obiskovalci opazili novo celostno grafično podobo. Slednja vključuje spremembo logotipa, barvne sheme, dopisne elemente in še več.

$\checkmark$ veliko veselje nam je, da smo vse vsebine $v$ celoti ohranili in osvežili kjer je bilo to mogoče $z$ novimi informacijami. Vsem uporabnikom so tako še vedno na voljo vsebine in orodja, ki smo jih pripravili v sklopu preteklega projektnega dela. Nekatere od teh so:

- Za preliminarno oceno stroškov smo na Gozdarskem inštitutu Slovenije razvili spletno orodje za vizualizacijo proizvodnih verig s spremljajočimi kalkulacijami, ki nastanejo v poslovnem procesu (proizvodnji, storitvi).

- S spletnim orodjem lahko določimo tehnične norme za konkretno delovišče na podlagi predpostavk, ki temeljijo na znanstvenem proučevanju dela, torej s snemanji in meritvami. WCM omogoča poenostavljen način določanja normativov gozdarskih del, pri katerem zadostujejo zgolj podatki o številu dreves, izbranih za sečnjo po drevesnih vrstah in debelinskih stopnjah ter nekaj osnovnih podatkov o tehnologiji in terenskih razmerah. Na podlagi osnovnih podatkov nam orodje samodejno izračuna osnovni čas, porabljen za izdelavo in spravilo dreves izbranih za sečnjo ter maksimalni čas, ki upošteva največje možne bonifikacije (pribitke časa k osnovnemu normativu). Osnovni rezultat je torej časovni interval. Za bolj zahtevne uporabnike je na voljo tudi podrobni izračun časovnega normativa, ki poleg osnovnih podatkov vključuje tudi bonifikacije na te čase (npr. zaradi dodatnih del, zahtevnejših terenskih ali vremenskih okoliščin itd.).

- V sklopu orodij je tudi orodje za pretvarjanje enot. Orodje sicer nima neposredne povezave s stroški, a je vseeno uporaben predvsem v praksi, kjer pri trgovanju z različnimi oblikami lesnih goriv večkrat prihaja do različnih interpretacij »kubika « prodanega lesa. Poleg tega je možno modul uporabiti za primerjavo med lesnimi in fosilnimi gorivi, slednje so pomembne, ko se odločamo o zamenjavi energenta. Modul nam na podlagi znanih podatkov o pretekli porabi (npr. kurilnega olja) poda približon količino potrebnih lesnih goriv. Potrebno je poudariti, da gre za približen izračun energijskih ekvivalentov, ki temelji na enačbi za analitični izračun kurilnosti in faktorjih za preračun v druge enote, ne upošteva pa dejanskega izkoristka kotla.

- Celovit sistem spremljanja cen, kjer poleg cen lesa spremljamo tudi cene storitev v gozdarstvu (sečnja in spravilo ter prevoz lesa). Celovit sistem smo vzpostavili leta 2017 v sklopu Javne gozdarske službe - GIS, medtem ko smo sistem spremljanja cen posameznih lesnih goriv na trgu razvili v sklopu projekta BiomassTradeCentres II in jih spremljamo po enotni metodologiji že od leta 2011 dalje.

- Vpogled v podatke o deležnikih gozdno-lesnih verig s pomočjo zemljevida Slovenije, kot so ponudniki gozdarskih storitev (sečnja, spravilo, gojenje, žično spravilo, strojna sečnja, izdelava sekancev), primarni proizvajalci lesa (žage, proizvodnja pelet in briket), proizvajalci gozdarske mehanizacije in strojev, gozdarske trgovine, strokovno-raziskovalne inštitutcije,...

- V interaktirvni obliki je na voljo zemljevid žagarskih obratov, ki smo ga pripravli v letu 2020, ko smo na Gozdarskem inštitutu Slovenije opravili raziskavo med žagarskimi obrati, z namenom ugotavljanja aktualnega stanja v slovenski žagarski industriji. Glavni cilj raziskave je bil razumeti dinamiko razvoja primarne lesnopredelovalne industrije $v$ Sloveniji, kar bo pripomoglo $\mathrm{k}$ oblikovanju učinkovitejših ukrepov in strategij nadaljnjega razvoja te panoge.

- Na voljo so informacije o ocenah dejanskih in teoretičnih tržnih potencialov okroglega lesa $v$ slovenskih gozdovih, ki so pomembne za vse akterje, vključene v gozdno-lesne verige. Kakovosten les oziroma hlodi so pomembni za podjetja, ki se ukvarjajo z nabavo, predelavo ali prodajo hlodov; to so predvsem žagarski obrati in proizvajalci furnirja ter proizvajalci vezanih furnirskih plošč. Les slabše kakovosti pa je pomemben predvsem za celulozno in kemično industrijo, proizvajalce lesnih plošč, proizvajalce lesnih goriv in energetska podjetja, ki proizvajajo in tržijo toploto in/ali elektriko, proizvedeno iz lesne biomase. 


\section{Novosti leta}

- V začetku leta 2021 smo predstavili spletno orodje / Učni pripomoček za določanje kakovosti posameznega sortimenta. Spletno orodje je namenjeno vsem uporabnikom, ki želijo na priročen način določiti kakovost hlodovine in obenem pridobiti znanje o vrednotenju gozdnih lesnih sortimentov.

- $\vee$ mesecu marcu in maju smo izvedli prvi dve spremljanji prodajnih cen žaganega lesa iglavcev v Sloveniji, ki smo jih ponovili še v mesecu avgustu in novembru. Vprašalnik posredujemo na 60 elektronskih naslovov. Opravljene raziskave nazorno kažejo dinamiko spreminjanja cen žaganega lesa na trgu. Menimo, da bi bilo spremljanje cen žaganega lesa smiselno tudi $v$ naslednjih letih. Zato nameravamo anketni vprašalnik revidirati (t.j., skrajšati obseg in nabor proizvodov ter vprašanj), da bo anketirancem čim bolj prijazen. Vsa podjetja, ki se ukvarjajo s to dejavnostjo tudi v prihodnje vljudno vabimo k sodelovanju, saj bodo le z zadostnim številom poročevalskih enot (podjetij) rezultati reprezentativni.

- Pripravili in objavili smo Kazalnike gospodarjenja z gozdovi. Priprava metodologije, izbor ter opis kazalnikov je rezultat projekta "Razvoj kazalcev in metodologije spremljanja ponudbe gozdarskih storitev (V4-1812)". Kazalniki gospodarjenja z gozdovi napovedujejo in nakazujejo stanje ter nakazuje razvoj gospodarjenja z gozdovi v Sloveniji. Kazalniki so predvsem količinski ali kakovostni podatki in so tako lahko pomembno orodje pri oblikovanje politik. Na gospodarjenje z gozdovi gledamo iz različnih zornih kotov, zajeti so tako okoljski kot socialni in ekonomski vidiki. Pri pripravi metodologije za izbor in prikaz kazalnikov gospodarjenja z gozdovi smo se zgledovali po kazalnikih okolja, ki jih pripravlja in objavlja Agencija za okolje Republike Slovenije (ARSO OKOLJE, http://kazalci.arso.gov.si). Kazalniki se ne podvajajo, ampak se dopolnjujejo, zato nismo razvijali kazalcev s področja okolja. Družbene in gospodarske kazalnike smo za boljšo preglednost dodatno razdelili v 6 kategorij.

\section{Arhiviranje in hramba starih elektronskih virov}

Med novostmi leta 2021 je tudi vzpostavitev trajne hrambe spletnih prispevkov v sklopu spletne publikacije InfoGozd - Skrbno z gozdom. V uredništvu smo izkoristili možnosti, ki nam jih ponuja digitalni repozitorij raziskovalnih organizacij Slovenije (Dirros). Vse prispevke, ki so bili objavljeni v letih 2020 in 2021 smo na takšen način arhivirali in s tem zagotovili trajnost. Prispevki so arhivirani v obliki mesečnih izdaj in so dostopni na povezavi digitalnega repozitorija raziskovalnih organizacij Slovenije (Dirros). Z arhiviranjem prispevkov bomo nadaljevali tudi v letu 2022. Prizadevali si bomo spletno publikacijo InfoGozd vključiti v različne bibliografske zbirke in s tem avtorjem in publikaciji zagotoviti čimvečjo odmevnost.

\section{Uredništvo InfoGozd}

Za redno objavo novic in tehnično dovršenost so tudi v letu 2021 z vsem zanosom skrbeli Mirko Baša, Tina Jemec in Urban Žitko. Ekipi si se pridružil še Jaša Saražin, Katarina Flajšman in Lovro Božidar Birkić. Objavili smo vrsto zanimivih prispevkov in še razširili področje delovanja. Poleg omenjenih vsebin smo v letu 2021 še naprej redno objavaljali aktualne novice s področja gozdne tehnike in ekonomike s poudarkom na gozdno-lesnih verigah, mehanizaciji in ekonomiki. Tudi v letu 2021 smo sodelovali s številnimi avtorji, ki so skupaj objavili 82 prispevkov. V sodelovanju z Zvezo gozdarskih društev Slovenije smo objavili 8 razširjenih strokovnih ali znanstvenih objav. Največ objav je tudi v letu 2021 pripravila avtorica Špela Ščap. 
$\mathrm{Na}$ tem mestu se zahvaljujemo vsem avtorjem za svoje prispevke in nenazadnje vam uporabnikom za zvestobo. Želimo si, da bi skupaj še tako uspešno delovali tudi v prihajajočem letu. V kolikor želite svoje vsebine objaviti v spletni publikaciji InfoGozd - Skrbno z gozdom nam jih posredujte na elektronski naslov uredništva. $V$ prvem četrtletju bomo na podstrani uredništva InfoGozd objavili več informacij o uredništvu (uredniška etika, založništvo) in predstavili podrobna navodila avtorjem za pripravo prispevkov primernih za objavo na spletni strani WCM/InfoGozd in spletni publikaciji InfoGozd - Skrbno z gozdom.

Vsekakor si bo ekipa oddelka za gozdno tehniko in ekonomiko na Gozdarskem inštitutu Slovenije še naprej prizadevala za nadaljni razvoj vsebin tudi v prihodnosti.

Predstavljamo še pet najbolj obiskanih vsebin v letu 2021.

\begin{tabular}{|c|c|c|}
\hline 1. & $\begin{array}{l}\text { Cene gozdno lesnih sortimentov } \\
\text { Gozdni lesni sortimenti (GLS) so definirani kot ves posekan les gozdnih } \\
\text { drevesnih vrst, in sicer s skorjo ali brez nje, in obsegajo: les v okrogli } \\
\text { obliki, razcepljen ali v drugi obliki (veje, korenine, panji in tvorbe) ter lesne } \\
\text { sekance iz lesa, pridobljenega neposredno v gozdu. Cene GLS so prav } \\
\text { tako kot gozdarske storitve odvisne od številnih dejavnikov, dodatno pa } \\
\text { na cene vplivajo razmere na trgu - ponudba in povpraševanje, ki se } \\
\text { spreminja skozi čas. Med dejavnike, ki določajo ceno GLS, sodijo: } \\
\text { kakovost, dimenzije, drevesna vrsta in čas poseka. }\end{array}$ & $\begin{array}{l}25.611 \\
\text { ogledov }\end{array}$ \\
\hline 2. & $\begin{array}{l}\text { Merjenje okroglega lesa } \\
\text { Merjenje in način izračunavanja volumna hlodov predstavlja stično točko } \\
\text { med prodajalcem in kupcem in je podlaga za plačilo blaga. Kljub temu, da } \\
\text { ta postopek na prvi pogled deluje enostavno, v izogib sporom že dolgo } \\
\text { obstajajo dogovorjena pravila bodisi v obliki uzanc, dogovorov, standardov } \\
\text { in pravnih predpisov. Merjenje količin in določanje kakovosti okroglega } \\
\text { lesa je ključno tako za lesnopredelovalno industrijo kot tudi za lastnika } \\
\text { gozdov in podjetja, ki se ukvarjajo s trgovanjem. }\end{array}$ & $\begin{array}{l}10.543 \\
\text { ogledov }\end{array}$ \\
\hline 3. & $\begin{array}{l}\text { Kalkulator enot } \\
\text { Za preglednejše trgovanje z različnimi oblikami lesnih goriv so koristni } \\
\text { (okvirni) pretvorbeni faktorji za preračun med različnimi enotami. Na } \\
\text { naslednji sliki so predstavljeni nekateri najbolj pogosto uporabljeni } \\
\text { pretvorbeni faktorji. Gre za okvirne vrednosti, saj lahko dejanske vrednosti } \\
\text { odstopajo zaradi različnih dejavnikov (gostota nasutja, velikost delcev, } \\
\text { itd.). }\end{array}$ & $\begin{array}{l}8.272 \\
\text { ogledov }\end{array}$ \\
\hline 4. & $\begin{array}{l}\text { Cene lesnih goriv } \\
\text { Merjenje in način izračunavanja volumna hlodov predstavlja stično točko } \\
\text { med prodajalcem in kupcem in je podlaga za plačilo blaga. Kljub temu, da } \\
\text { ta postopek na prvi pogled deluje enostavno, v izogib sporom že dolgo } \\
\text { obstajajo dogovorjena pravila bodisi v obliki uzanc, dogovorov, standardov } \\
\text { in pravnih predpisov. Merjenje količin in določanje kakovosti okroglega } \\
\text { lesa je ključno tako za lesnopredelovalno industrijo kot tudi za lastnika } \\
\text { gozdov in podjetja, ki se ukvarjajo s trgovanjem. Med meritvami bomo v } \\
\text { nadaljevanju obravnavali načine izmere količin okroglega lesa, določanje } \\
\text { kakovosti, razmerja med maso in volumnom ter področje standardizacije. }\end{array}$ & $\begin{array}{l}6.098 \\
\text { ogledov }\end{array}$ \\
\hline
\end{tabular}




\section{Lesni sekanci}

- Sekanci so zdrobljena lesna biomasa v obliki koščkov določene velikosti, ki se izdelujejo z mehansko obdelavo z ostrim orodjem. Lesni sekanci so nepravilne štirikotne oblike, značilne dolžine od 3 do $45 \mathrm{~mm}$ in z majhno debelino v primerjavi z drugimi dimenzijami. 